\title{
Barriers of Poles' Participation in Lifelong Learning Process - A Multivariate Analytical Approach
}

\author{
Alicja Grześkowiak \\ Wrocław University of Economics \\ Email: alicja.grzeskowiak@ue.wroc.pl
}

Doi:10.5901/jesr.2014.v4n4p21

\begin{abstract}
Lifelong learning is an important element of European Union educational strategies. Unfortunately, in Poland the percentage of people who have completed formal education and undertake further training is at a very low level and turns out to be very poor in comparison with other European countries. This study examines the barriers to educational involvement on the basis of the data provided by a Polish nationwide survey on human capital. According to the nature of the data used in this study, selected multidimensional methods are applied to facilitate the identification of the relationships among the barriers of lifelong learning participation as well as their associations with a set of socio-economic characteristics. Clustering procedure is used to detect the possible groups of factors and logistic regression approach is applied to examine the impact of socio-economic issues.
\end{abstract}

Keywords: lifelong learning, cluster analysis, logistic regression

\section{Introduction}

Education is an important element of European strategic objectives. European programmes concerning education entitled Education and Training 2010 (ET2010) and subsequent Education and Training 2020 (ET2020) give a set of targets to be achieved in Member States. One of the areas of particular interest is adult lifelong learning participation. Benchmarks concerning this phenomenon were specified in ET2010 and ET2020 strategies. The desired level of adult education engagement was set as on average at least of $15 \%$ of the adult working population i.e. 25-64 age group (Council conclusions..., Annex I). The target has been not achieved in Europe yet, as according to Eurostat data in 2013 the EU28 average was equal to $10,4 \%$. This indicator for Poland differs essentially from the European average taking value of $4,3 \%$ only. Moreover, adult lifelong learning involvement tends to be the weakest part of the educational system in Poland in relation to the benchmarks defined in ET programmes (cf. Grześkowiak \& Stanimir, 2013). This unfavorable situation needs further examinations. Although some quantitative studies concerning this topic are available (Czapiński \& Panek, 2009; Czapiński \& Panek, 2011, Czapiński \& Panek, 2013 ; Grześkowiak, 2013) they are focused on the fact of participation and do not concern the set of possible barriers.

The purpose of this paper is to analyze barriers to lifelong learning participation of Poles. Two main objectives of the study are as follows:

- assessment of interdependences of barriers based on classification procedures,

- evaluation of dependences between barriers and socio-economic factors with respect to logistic regression outcomes.

The research is based on survey results which contain categorical data (nominal and ordinal) as well as metric one. Since the analyses are performed using a dataset dominated by non-metric variables specific tools were chosen to examine the relationships among the considered features.

\section{Data Characteristics and Analytical Methods}

This research is based on data available from the third wave of a nationwide survey on human capital named Bilans kapitału ludzkiego 2012. The survey was carried out in Poland in 2012 resulting in an extensive database allowing for various analyses concerning labour market. This study uses data collected from individuals in productive age (i.e. 18-64 for men and 18-59 for women) under population/society survey being a part of the mentioned above project. The number of valid cases concerning obstacles to lifelong learning is equal to 14244 . Two types of variables are taken into consideration: firstly, main barriers to educational involvement in last 12 months declared by respondents, secondly, socio-economic factors. The sets of variables are presented in Table 1 and Table 2. 
Table 1. List of main barriers to participation in lifelong learning activities (last 12 months)

\begin{tabular}{lc}
\hline \multicolumn{1}{c}{ Variable } & Coding \\
\hline Not needed in my work & $0-$ no, 1-yes \\
Did not meet the formal requirements to participation in courses/training & $0-$ no, 1-yes \\
Courses/trainings were too expensive & $0-$ no, 1-yes \\
No support/encouragement from employer & $0-$ no, 1-yes \\
No time for professional reasons & $0-$ no, 1-yes \\
No time for personal reasons & $0-$ no, 1-yes \\
No interesting courses/training close to my place of residence & $0-$ no, 1-yes \\
No motivation to further education & $0-$ no, 1-yes \\
Health condition did not allow me to training & $0-$ no, 1-yes \\
It does not make sense to re-skill in my age & $0-$ no, 1-yes \\
Previous courses/training gave me a little & $0-$ no, 1-yes \\
\hline
\end{tabular}

Source: own elaboration based on variables from the survey ("Bilans kapitału...", 2012, p.24)

As it can be seen from Table 1 the listed obstacles to educational involvement are various in nature. They comprise both professional and personal reasons as well as previous experience and external issues. Actually, this enumeration was accompanied in the questionnaire by the answers "others" and "hard to say" but these variants are omitted in further considerations. Table 2 shows a set of socio-economic characteristics which may have an influence on the lack of participation in continuous education.

Table 2. List of socio-economic characteristics under consideration

\begin{tabular}{ll}
\hline \multicolumn{1}{c}{ Variable } & \multicolumn{1}{c}{ Coding } \\
\hline Gender & 0 - men, 1 - woman \\
Age & number of years \\
Educational level & 0 - lower levels, 1 - upper secondary, 3 - tertiary \\
Labour market status (LFS) & 0 - not working, 1 - working \\
Place of residence & 0 - rural, 1 - urban \\
\hline
\end{tabular}

Source: own elaboration based on variables from the survey Bilans kapitału ludzkiego 2012

According to the objectives of the study two multivariate techniques are used to reveal certain information. The first one is a hierarchical clustering procedure applied to examine relationships among various barriers to participation in lifelong learning. As indicated by Bartholomew et al. $(2008$, p.18) classification is a crucial method of scientific inquiry, particularly in social sciences in case of searching for some patterns in a dataset when no underlying theory is given. There are two main types of clustering algorithms: hierarchical and non-hierarchical. Hierarchical agglomerative methods start by treating each observation (or variable) as a single cluster and in successive steps the two closest clusters are combined until all observations are included (Afifi \& Clark, 1996, p. 391). The whole process can be presented visually as dendrogram which can be also helpful in choosing the number of homogeneous groups. The selection of the final number of clusters is not an unequivocal issue and may be done according to the distances between clusters at consecutive steps (Afifi \& Clark, 1996, p. 395). Although the hierarchical agglomerative procedures are based on the same general idea, their variants differ according to the definition of the distance between two clusters (see e.g. Rencher \& Christiansen, 2012).

The other analytical technique used in this study is logistic regression applied to examine the possible influence of socio-economic factors on the declaration of barriers to educational involvement. Logistic regression modeling is used to describe the relationship of several independent variables to a dichotomous dependent variable (Kleinbaum \& Klein, 2010, pp.4-5), i.e. a variable which takes only two values, in our case zero and one. One of the possible notation is given by the formula:

$\ln \left(\frac{p_{i}}{1-p_{i}}\right)=\beta_{0}+\beta_{1} X_{1}+\cdots+\beta_{m} X_{m}$

where: $\mathrm{pi}$ - probability that the dichotomous variable takes value 1 (so called success),

$\mathrm{X} 1, \ldots, \mathrm{Xm}$ - independent variables,

$\beta_{0}, \ldots, \beta_{m}$ - parameters. 
The parameters of the equation (1) are estimated by maximum likelihood method and the expression $\exp \left(\hat{\beta}_{i}\right)$ is interpreted as odds ratio. Its value greater than 1 indicates that as an independent variable increases the ratios pi/(1-pi) also increase, and its value lower than 1 reveals changes in an opposite direction.

Both classification procedure and logistic regression estimation are done with application of IBM SPSS Statistics 21.

\section{Classification of the Barriers of Lifelong Learning Participation}

Classification of the obstacles indicated by the respondents is performed by the means of a hierarchical algorithm. Each agglomerative clustering procedure begins with the calculation of the distance matrix. As the variables representing barriers to lifelong learning are binary, an appropriate dissimilarity measure must be chosen. In this study one of the most popular measures of association for $2 \times 2$ tables is applied, i.e. Yule's Q (see Reynolds, 1984, p.41-42). The distances between clusters are calculated according to centroid method in which the distance is defined as Euclidean one between the mean vectors of the two considered clusters. The visual representation of the clustering process is presented in Figure 1.

The dendrogram in Figure 1 shows the successive stages of agglomeration. The linkage schedule suggests the possibility of division into five groups. The place of the division is indicated by the dashed line. Hence, the classification of barriers to lifelong learning activities is as follows:

- Cluster 1: "not needed in my work",

- Cluster 2: "health condition did not allow me to training", "it does not make sense to re-skill in my age",

- Cluster 3: "no support/encouragement from employer", "no time for professional reasons", "no time for personal reasons",

- Cluster 4: "previous courses/training gave me a little", "no interesting courses/training close to my place of residence", "no motivation to further education",

- Cluster 5: "did not meet the formal requirements to participation in courses/training", "courses/trainings were too expensive".

Figure 1. Results of hierarchical clustering procedure, division into five clusters marked by the dashed line

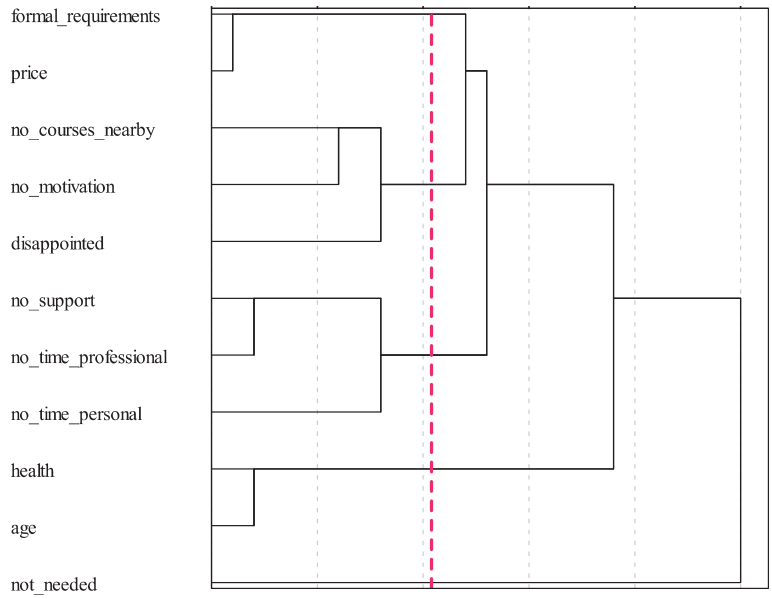

Source: own computations done with IBM SPSS Statistics 21

First of all it should be noted that the lack of need for training constitutes a separate cluster, moreover incorporated in the tree chart in the last step of the procedure, what allows us to conclude that this reason is the least related to the others. Two factors are often indicated simultaneously: health problems and the conviction that at a certain age it does not make sense to learn new things. The third group of causes is related to being short of time, both for professional and private reasons, and the lack of encouragement or support from the employer. It is worth underlying that there is a bigger similarity between the employer's attitude and the shortage of time due to professional obligations than in relation to the 
lack of time in private life. Another group of barriers is associated with personal attitude and previous experience of the respondents who are not sufficiently motivated to take action to enhance their skills and competences. In part this may be due to bad experiences and beliefs that educational activities contribute little to professional and private life of the individual. Another problem is the lack of availability of interesting trainings in the immediate vicinity of the place of residence of the respondents. The last group are the obstacles resulting from non-compliance with the formal requirements and too high costs of education.

\section{Barriers of Participation with Respect to Socio-Economic Characteristics}

The impact of various socio-economic factors on declaring certain barriers to lifelong participation is evaluated by logistic regression analysis. As eleven potential obstacles are considered, eleven logistic regression models are estimated. The odds ratios corresponding to particular socio-economic characteristics are shown in Table 3 . The $\exp \left(\hat{\beta}_{i}\right)$ values reflect if the probability of indicating a given obstacle decreases or increases as the category of an independent variable is changed. The values should be regarded in reference to referent category written at the top of the table (corresponding to coding "0" in Table 2). Statistically significant parameters are marked with asterisks.

Table 3. Results of logistic regression analysis

\begin{tabular}{|c|c|c|c|c|c|c|}
\hline \multirow{4}{*}{ Barrier } & \multicolumn{6}{|c|}{ Estimates: $\exp \left(\hat{\beta}_{i}\right)$} \\
\hline & Gender & Age & & sational level & Labor market status & Place of residence \\
\hline & \multicolumn{6}{|c|}{ Referent category } \\
\hline & \multicolumn{4}{|c|}{$\begin{array}{c}\text { Rerer } \\
\text { lower levels }\end{array}$} & not working & rural \\
\hline Not needed in my work & $0,877^{\star \star}$ & $1,011^{* *}$ & $\begin{array}{l}1 \\
2\end{array}$ & $\begin{array}{c}1,114^{*} \\
0,984\end{array}$ & $5,827^{\star *}$ & 0,988 \\
\hline It does not make sense to re-skill in my age & $1,253^{\star *}$ & $1,099^{* *}$ & $\begin{array}{l}1 \\
2\end{array}$ & $\begin{array}{l}0,720^{\star \star} \\
0,407^{\star \star}\end{array}$ & $0,313^{* *}$ & $0,744^{\star *}$ \\
\hline Health condition did not allow me to & 0,888 & $1,064^{\star *}$ & $\begin{array}{l}1 \\
2 \\
\end{array}$ & $\begin{array}{l}0,749^{\star \star} \\
0,604^{\star}\end{array}$ & $0,081^{\star *}$ & 0,952 \\
\hline No interesting courses nearby & 1,107 & $0,981^{\star *}$ & $\begin{array}{l}1 \\
2\end{array}$ & $\begin{array}{l}1,109 \\
1,056\end{array}$ & $0,600^{* *}$ & $0,644^{\star *}$ \\
\hline No motivation to further education & 1,139 & $1,011^{\star *}$ & $\begin{array}{l}1 \\
2\end{array}$ & $\begin{array}{c}0,978 \\
0,614^{\star *}\end{array}$ & 0,460 ** & 0,894 \\
\hline Previous courses gave me a little & 1,205 & 1,004 & $\begin{array}{l}1 \\
2\end{array}$ & $\begin{array}{l}1,041 \\
0,972\end{array}$ & 0,803 & 1,065 \\
\hline No support from employer & 1,266 & $0,989^{*}$ & $\begin{array}{l}1 \\
2\end{array}$ & $\begin{array}{c}0,992 \\
0,630^{*}\end{array}$ & $3,214^{\star *}$ & $1,412^{\star *}$ \\
\hline No time for professional reasons & $0,819^{*}$ & $0,980^{* *}$ & $\begin{array}{l}1 \\
2\end{array}$ & $\begin{array}{c}1,104 \\
1,500^{\star \star}\end{array}$ & $4,463^{* *}$ & 1,048 \\
\hline No time for personal reasons & $1,998^{\star *}$ & $0,978^{\star *}$ & $\begin{array}{l}1 \\
2\end{array}$ & $\begin{array}{l}1,171^{*} \\
1,334^{\star *}\end{array}$ & $0,418^{* *}$ & $0,804^{\star \star}$ \\
\hline Courses/trainings were too expensive & 1,023 & $0,981^{\star *}$ & $\begin{array}{l}1 \\
2\end{array}$ & $\begin{array}{l}0,877 \\
0,793\end{array}$ & $0,661^{* *}$ & $1,241^{*}$ \\
\hline Did not meet the formal requirements & 0,969 & $0,988^{* *}$ & $\begin{array}{l}1 \\
2\end{array}$ & $\begin{array}{c}0,789 \\
0,587^{*}\end{array}$ & $0,284^{\star *}$ & $0,744^{\star *}$ \\
\hline
\end{tabular}

${ }^{*} p<0,05,{ }^{* *} p<0,01$

Source: own computations done with IBM SPSS Statistics 21

A high degree of detail in Table 3 makes it difficult to obtain quick and general outlook on the phenomena. A type of results visualization is proposed in Table 4 to facilitate the perception of the directions of influence (if any). The table cells corresponding to the variables with significant influence are marked in color and those with no importance are left white. Dark colored cells indicate odds ratio greater than 1 and light colored cells signify odds ratio lower than 1.

Table 4. Visualization of impact of socio-economic characteristics 


\begin{tabular}{|c|c|c|c|c|c|c|}
\hline Barrier & $\begin{array}{l}\frac{\bar{d}}{\bar{D}} \\
\text { ভ }\end{array}$ & 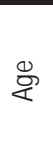 & 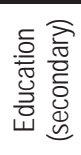 & 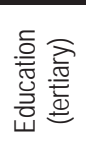 & 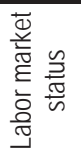 & 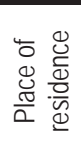 \\
\hline \\
\hline \multicolumn{7}{|c|}{ It does not make sense to re-skill in my age } \\
\hline \multicolumn{7}{|c|}{ Health condition did not allow me to } \\
\hline \multicolumn{7}{|l|}{ No interesting courses nearby } \\
\hline \multicolumn{7}{|l|}{ No motivation to further education } \\
\hline \multicolumn{7}{|l|}{ Previous courses gave me a little } \\
\hline \multicolumn{7}{|l|}{ No support from employer } \\
\hline \multicolumn{7}{|l|}{ No time for professional reasons } \\
\hline \multicolumn{7}{|l|}{ No time for personal reasons } \\
\hline Courses/trainings were too expensive & & & & & & \\
\hline Did not meet the formal requirements & & & & & & \\
\hline
\end{tabular}

Blank fields - not significant, dark colored fields - significant with positive impact (in comparison to referent category), light colored fields - significant with negative impact (in comparison to referent category). Referent categories as in Table 3.

\section{Source: own elaboration}

Only in one case ("Previous courses gave me a little") none of socio-economic factors have significant impact. For two reasons ("It does not make sense to re-skill in my age", "No time for personal reasons") all of the considered variables show significant influence. Key findings regarding reasons for not training in the last year are as follows:

- men, older people and persons with secondary education (compared to those with primary) are more likely to indicate the reason "Not needed in my work",

- $\quad$ women and older people have a greater inclination to declare the barrier "It does not make sense to re-skill in my age"; on the contrary, secondary or tertiary education level, "working" status and living in town/city decrease the probability of indicating this response,

- the probability of pointing out limitations associated with health condition increases with age, but is lower for better educated and having "working" status,

- being a working person, residing in the town/city, having an advanced age reduce the probability of the answer that there are no interesting courses nearby,

- $\quad$ higher age increases the chance of lack of motivation for further education, while tertiary education level and "working" status trim it down,

- the probability of indicating the barrier "No support from employer" is higher for people living in urban areas, but age and tertiary education level have the opposite impact,

- women have a lower tendency to point out the lack of time for professional reasons, but greater of personal reasons,

- higher level of education stimulates the probability of declaring the lack of time for professional reasons,

- $\quad$ higher age decreases the possibility of indicating the lack of time (both for professional and personal reasons) as an obstacle to education,

- working persons and living in urban areas are less likely to declare the lack of time for personal reasons,

- $\quad$ higher age reduces the chance of responses "Courses/trainings were too expensive", "Did not meet the formal requirements", similar impact is shown by "working" status,

- tertiary education level and urban place of residence reduce the chance of selecting the answer "Did not meet the formal requirements".

It should be underlined that each of the aforementioned factors affecting the educational barriers declaration must be interpreted separately at a controlled impact of other factors considered.

\section{Conclusions}

The multivariate methods applied in this study allow to describe some aspects of barriers to lifelong learning process in Poland. Agglomerative clustering procedure reveals that some of the obstacles to continuous education coexist. There is one reason not combined with the others - the conviction that the training is not needed for person's work. Remarkable 
interdependence can be observed between health problems and unwillingness to learning because of advanced age as well as between lack of time and no support from the employer. The considered socio-economic factors as gender, age, educational level and place of residence have various impact on the declaration of particular barriers. The knowledge of the effects of these factors may be helpful when developing the policy on lifelong learning.

\section{Acknowledgments}

This study was done under the project "Non-metric multivariate data analysis as a tool for study of adults situation in the context of demographic changes" financed by Narodowe Centrum Nauki (National Science Centre) in Poland. Project number: 2012/05/B/HS4/02499.

The data on individuals come from the database Bilans Kapitału Ludzkiego - 2012 and were retrieved on 2014-0107.

\section{References}

Afifi, A., \& Clark, V. A. (1996). Computer-aided multivariate analysis. Springer-Science+Business Media, B.V. Bartholomew, D. J., Steele, F., Galbraith, J., \& Moustaki, I. (2008). Analysis of multivariate social science data. CRC Press.

Bilans kapitału ludzkiego w Polsce. Badania ludności (2012)

http://bkl.parp.gov.pl/system/files/Downloads/20120917112349/BKL_kwest_ludno_3_edycja_final_.pdf?1347873882 (retrieved 2014-0425)

Council conclusions of 12 May 2009 on a strategic framework for European cooperation in education and training ('ET 2020'), Official Journal of the European Union 2009/C 119/02

http://eur-lex.europa.eu/legal-content/EN/ALL/?uri=CELEX:52009XG0528(01) (retrieved 2014-05-16)

Czapiński, J. \& Panek, T. (Eds.). (2009). Diagnoza społeczna 2009. www.diagnoza.com; retrieved 2013/07/24

Czapiński, J. \& Panek, T. (Eds.). (2011). Diagnoza społeczna 2011. www.diagnoza.com; retrieved 2013/07/24

Czapiński, J. \& Panek, T. (Eds.). (2013). Diagnoza społeczna 2013.

www.diagnoza.com; retrieved 2014/05/15

Grześkowiak, A. (2013). Statystyczna analiza aktywności edukacyjnej osób dorosłych w Polsce. Ekonometria 2(40)

Grześkowiak, A., \& Stanimir, A. (2013). Multivariate Analysis of Determinants of the Implementation of European Strategic Educational Objectives in Poland. Academic Journal of Interdisciplinary Studies, 2(3), 351.

Kleinbaum, D. G., \& Klein, M. (2010). Logistic regression: a self-learning text. Springer.

Rencher, A. C., \& Christensen, W. F. (2012). Methods of multivariate analysis, John Wiley \& Sons.

Reynolds H. T. (1984). Analysis of nominal data, Sage University Paper series on Quantitative Application in the Social Sciences, series no. 07-001, Beverly Hills and London 